\title{
South Africa's service-delivery crisis: From contextual understanding to diaconal response
}

\begin{tabular}{|c|c|}
\hline \multicolumn{2}{|c|}{$\begin{array}{l}\text { Author: } \\
\text { Ignatius Swart }{ }^{1}\end{array}$} \\
\hline \multicolumn{2}{|c|}{$\begin{array}{l}\text { Affiliation: } \\
{ }^{1} \text { Research Institute for } \\
\text { Theology and Religion, } \\
\text { University of South Africa, } \\
\text { South Africa }\end{array}$} \\
\hline \multicolumn{2}{|c|}{$\begin{array}{l}\text { Note: } \\
\text { This article was initially } \\
\text { a paper delivered at the } \\
\text { annual meeting of the } \\
\text { Society for Practical Theology } \\
\text { in Potchefstroom, } 23-25 \\
\text { January } 2013 \text {. The theme } \\
\text { of the conference was } \\
\text { 'Practical theology and } \\
\text { service delivery'. This article } \\
\text { is published in the Section } \\
\text { Practical Theology of the } \\
\text { Society for Practical Theology } \\
\text { in South Africa. }\end{array}$} \\
\hline \multicolumn{2}{|c|}{$\begin{array}{l}\text { Correspondence to: } \\
\text { Ignatius Swart }\end{array}$} \\
\hline \multicolumn{2}{|c|}{$\begin{array}{l}\text { Email: } \\
\text { swarti1@unisa.ac.za }\end{array}$} \\
\hline \multicolumn{2}{|c|}{$\begin{array}{l}\text { Postal address: } \\
\text { PO Box 392, UNISA, Pretoria } \\
\text { 0003, South Africa }\end{array}$} \\
\hline \multicolumn{2}{|c|}{$\begin{array}{l}\text { Dates: } \\
\text { Received: } 20 \text { Apr. } 2013 \\
\text { Accepted: } 12 \text { July } 2013 \\
\text { Published: } 10 \text { Sept. } 2013\end{array}$} \\
\hline \multicolumn{2}{|c|}{$\begin{array}{l}\text { How to cite this article: } \\
\text { Swart, I., 2013, 'South } \\
\text { Africa's service-delivery } \\
\text { crisis: From contextual } \\
\text { understanding to diaconal } \\
\text { response', HTS Teologiese } \\
\text { Studies/Theological Studies } \\
69(2), \text { Art. \#1996, } 16 \text { pages. } \\
\text { http://dx.doi.org/10.4102/ } \\
\text { hts.v69i2.1996 }\end{array}$} \\
\hline \multicolumn{2}{|c|}{$\begin{array}{l}\text { Copyright: } \\
\text { (C) 2013. The Authors. } \\
\text { Licensee: AOSIS } \\
\text { OpenJournals. This work } \\
\text { is licensed under the } \\
\text { Creative Commons } \\
\text { Attribution License. }\end{array}$} \\
\hline \multicolumn{2}{|l|}{ Read online: } \\
\hline 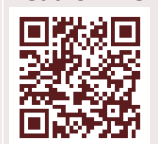 & $\begin{array}{l}\text { Scan this QR } \\
\text { code with your } \\
\text { smart phone or } \\
\text { mobile device } \\
\text { to read online. }\end{array}$ \\
\hline
\end{tabular}

This article proceeded from the assumption that the theme of service delivery in presentday South Africa could well be qualified by the notion of 'crisis', to the extent that this qualification, from a theological perspective and on the basis of comparative social analysis, well recalls the statements in such critical and profound theological documents as The Kairos Document and Evangelical Witness in South Africa on the 'crisis' in the latter years of apartheid. The further recognition that the theme of service delivery constitutes an essentially new focus for practical-theological scholarship in South Africa led the author, who has a pertinent interest in the field of Christian diaconia, to thereupon go the full circle of practical-theological interpretation in developing such a focus. This was done by, firstly, attempting to develop a deeper contextual understanding of the problem of service delivery in the country on the basis of the prevailing debate on service delivery in South Africa, after which the ideas from conceptualisations of two different modes of diaconal practice within contexts of endemic poverty in the practical-theological literature were explored. The discussion concluded with a more pertinent consideration of the extent to which these two conceptualisations could be taken as providing direction in conceptualising a transformational diaconal response to the current service-delivery problem.

\section{Introduction}

Towards the end of apartheid in South Africa, two of the most profound and critical theological documents from this period, The Kairos Document and Evangelical Witness in South Africa, both used the notion of 'crisis' to describe the situation in the country. In its first paragraph, The Kairos Document (1988:7) proclaimed that South Africa had been plunged into a crisis that was shaking its foundations and that there was every indication that the crisis had only just begun and that it would deepen and become even more threatening. Accordingly, this signalled a moment of truth (kairos), 'not only for apartheid but also for the church and all other faiths and religions' (The Kairos Document 1988:7) in the country. At the beginning of its first chapter, under the heading 'Crisis', Evangelical Witness in South Africa referred even more expressively to a 'socio-political crisis' in which 'the death and injury toll in the townships has continued to escalate ... while state repression and harassment have continued unabated' (Concerned Evangelicals 1986:4). The document continued in this vein to state on behalf of 'concerned evangelicals' in the country:

Called as we are to minister good news, we find ourselves in the mist of bloodshed and death, of increasing bitterness and polarisation, and of rising anger in the townships. Our proclamation, therefore, has been swallowed up by the cries of the poor and oppressed that it is now even impossible to hold conventional evangelistic campaigns in this war situation. These voices have become so loud that it has become impossible to hear the church preach. (Concerned Evangelicals 1986:4)

Indeed, 27 years after both documents stated their profound critique of a social crisis, it appears as if the much vaunted idea of South Africa as 'another country' (De Gruchy \& Ellis 2008) is fast losing its appeal. As if in a nightmare, in contemporary South African society, community and mass protests reminiscent of the days of apartheid are repeating themselves all over again, to the extent that it could well be claimed that the two aforementioned documents have lost little of their relevance. Whereas it could be said that the targets are very different now to what they were in the time of apartheid (Holden 2012:333), in contemporary South Africa, social commentators are drawing our attention to the way in which the anger of South Africa's desperately poor black communities is once again boiling over (as it did in the time of apartheid) (Davids 2012a, 2012b; Patel 2012; Saunderson-Meyer 2012) as they are protesting ever more violently and vehemently against their living conditions and what appears, on the surface, to be their grievances against inadequate or totally absent service delivery on the part of their local municipalities. Similarly, as in the time of apartheid, what is once again emerging is unrest on a national scale - disturbingly described by sociologist Peter Alexander as 'a massive rebellion of the poor' (Alexander 2012:34) - which raises serious questions about the state of democratic governance in contemporary South Africa. According to Paul Holden's very recent analysis, in which he has drawn the following 
parallel between this growing unrest and that which preceded it in apartheid South Africa:

In the late 2000s, South Africa exploded in a series of often violent protests. Nearly always, the location was the old 'location' - townships that featured a smattering of formal housing, shacks and over 50 per cent unemployment. The civic action was quickly described as 'service delivery' protests. These protests were about the failure of the state to deliver housing, electricity, sanitation and other services to areas of the country that had not changed substantially since the end of apartheid ... The images that emerged from the service delivery protests were eerily familiar: they looked much like those in the dying days of apartheid. Poor black South Africans were toyi-toying and marching to express their grievances. The protests sometimes spiralled into running battles with the police, with flaming barricades erected, or infrequently escalated into arson attacks on the houses of local councillors as well as amenities such as libraries and community halls. The resonance with the past was amplified by the fact that the areas in which the protests happened did not look much different than they had under apartheid - a reflection of the staggered and uneven nature of post-apartheid delivery.

In many ways, the service delivery protests looked as if they were intent in making townships ungovernable, much as they had been in the years of protest that eventually led to apartheid's demise. Disturbingly familiar too, was the response of the police, which was disastrously heavy-handed, leading to multiple injuries. In the case of Andries Tatane, a 33-year-old protestor in Ficksburg, police action led to death. Tatane was fatally beaten by a number of police officers without provocation in April 2011. Thus, despite the targets being much different in 2009 than they were in 1989, and the police staffed by a whole host of new recruits, the 'repertoire' of protest and state response was largely unchanged. (Holden 2012:332-333)

On the basis of the introductory discussion so far, this article proceeds from the assumption that the theme of service delivery in present-day South Africa could well be qualified by the notion of 'crisis', to that extent that this qualification, from a theological perspective and on the basis of comparative social analysis, well recalls the statements in such critical and profound theological documents as The Kairos Document and Evangelical Witness in South Africa on the 'crisis' in the latter years of apartheid. Steered by this initial understanding - and as a response to the decision by the Society of Practical Theology in South Africa to devote its 2013 meeting to a theme as topical as that of 'Practical theology and service delivery' - my attempt in this article to make a contribution to the topic will first of all be qualified by my claim that the theme of service delivery should be regarded as an essentially 'new' topical focus for practical theology in South Africa. Being presented therefore with the challenge to go the full circle of practical-theological interpretation (Osmer 2008:11; cf. Heitink 1999:163-170, 178-179) in order to make a meaningful contribution to the topic, I intend in a modest way to address the different questions emanating from the various tasks in this circle (the descriptive-empirical, interpretative, normative and pragmatic tasks as identified by Richard Osmer 2008:4) by embarking on the following enquiries:
- I will address the questions 'What is going on?' and 'Why is it going on?' (Osmer 2008:4) by seeking to develop a deeper contextual understanding of the nature and dynamics of the current service-delivery crisis. More specifically, I am conscious of the fact that we are here dealing with a problem that emanates from social dynamics in society at large, outside the direct domain of the Christian church, but I also take into account the complete lack of any practical-theological attempt to date to undertake its own empirical exploration of the problem. Accordingly, my intention here will be to develop this contextual understanding by drawing attention to, and exploring perspectives from, the prevailing South African service-delivery debate conducted by critical social-science scholars and social commentators.

- I will address the questions 'What ought to be going on?' and 'How might the Christian church or faith community respond?' (Osmer 2008:4) specifically from the perspective of an interest in the field of Christian diaconia and how the Christian church could, through this dimension of its ministry, make a transformational difference in its own authentic way where South African communities of poor people are suffering under the crisis. In particular, I intend considering the contributions of two scholars of practical theology - Hendrik Pieterse from South Africa and Susanne Johnson from the USA - to conceptualise modes of diaconal practice in contexts of endemic poverty and to reflect on the merits of their contributions in the light of the contextual insights developed in the first part of the article.

\section{South Africa's service-delivery crisis: Towards a deeper understanding}

A few articles may be identified in the existing corpus of post-apartheid South African practical-theological literature that dealt explicitly with the theme of service delivery (Erasmus \& Mans 2005; Hendriks, Erasmus \& Mans 2004; Manala 2010). Yet, it is important to point out that, in this small corpus of literature, only one contribution could be identified as engaging directly with the social and political dynamics of the country's current service-delivery crisis: a 2010 article by M.J. Manala, a practical theologian at the University of South Africa, which was published as part of a special issue on 'Black Theology in a South African Context' in the journal Scriptura.

My aim here is not to become involved in a polemical discussion about the exclusive claim made by Manala that Black Theology and the Black church is the Christian constituency in South Africa 'most suited' to address the service-delivery problem (Manala 2010:527). Instead, I rather want to credit Manala with doing what no other practical theologian in South Africa has done to date, namely to become involved in the increasingly prominent political debate about service delivery in the country and to initiate a theological awareness and consciousness regarding the problem. Clearly, his article makes a strong moral judgement 
on the current state of public service delivery in the country on the basis of his own attempt at contextual analysis (see Manala 2010:520-525). At the centre of this judgement-which notably involves a strong critique of the degree to which greed and corruption amongst local-government employees are disenabling service delivery (Manala 2010:523-524) - is the question (given the delay in quality service delivery) of how long Black South Africans still have to wait for the African National Congress's 'better life for all' promised in its 1994 National Election Manifesto (Manala 2010:519-520, 525). This leads him to argue, under a heading on the issue of service-delivery protests, that it is the constitutional right of those who suffer under poor or a lack of service delivery to protest as this offers 'the only way open to them for expression of their grievances, dissatisfaction and demands since they were not given an opportunity and a hearing' (Manala 2010:521; see also pp. 523, 528).

One find in Manala's extended argument a motion of condolence with - rather than any kind of qualified condemnation of the use of violence by - community protestors. He concedes at one point that ' $[s]$ ome of the protests are indeed reminiscent of the apartheid era protests' and that ' $[t]$ hey are at times violent and destructive of the country's most valued properties' (Manala 2010:521). For him, however, what needs to be condemned is the use of police brutality in dealing with the protests as this 'fuels the frustration and anger of communities leading to violence' (Manala 2010:523). Manala emphasises in conclusion that community protests and the resultant expressions of frustration and anger by the protestors could essentially be explained by 'communities' lack of participation in the local government structures and processes' (Manala 2010:523). Protest is their constitutional right and will not only give them 'an opportunity to monitor governance and administrative projects and processes of the local government' but also 'forge good relationships' with local government (Manala 2010:523).

I want to acknowledge again at this point the value of Manala's article as a source assisting practical-theological scholarship to begin to identify and understand the critical issues that are at stake in the debate on South Africa's servicedelivery crisis. However, whilst acknowledging this glimpse of identification and understanding that his contribution offers, it does not detract from the point that I would like to uphold in this article about the essential newness of the topical focus on the service-delivery crisis for South African practical-theological scholarship.

Even acknowledged as a single contribution within a small corpus of literature that has made a direct contribution to this focus, the perspective offered by Manala certainly cannot (as a single contribution) exploit the full complexity of the servicedelivery problem. At the same time, however, this limited exploration even more concerns the diaconal perspective that I have identified as the ultimate interest of my present article, as well illustrated by what Manala's article has to offer in response to his emphasis in the penultimate section of his article on the need for Black Theology to avoid being 'philosophical about the suffering of the poor' and become 'practically involved' in the service-delivery struggle (Manala 2010:528). Although this is in itself a very important statement from a practical-theological (and by implication diaconal) point of view, it is in his own response to this statement that one clearly encounters a limited attempt to start giving some substance and perspective to the statement. Thus, in what is surely the shortest part of his article, it becomes noticeable how Manala confines his practical perspective in the final section of the article to a statement about the bridge-building role that Black Theology (as the means of intervention by the Black church) should play in building a new relationship of commitment and cooperation between local government authorities and residents (Manala 2010:529). Clearly, I would like to argue here that this cannot be considered as a sufficient or complete practical-theological and diaconal response to a very complex problem, which reaffirms my point that an undertaking is required that will, in a new way, go the full circle of practical-theological interpretation in order to gain deeper understanding and perspective on a topical focus as essentially new as the one on South Africa's service-delivery crisis.

This seems to be an appropriate moment to return to my stipulated intentions in the introduction of this article in order to, first of all, develop - along the beacons of practicaltheological interpretation presented by Osmer - a deeper contextual understanding of the nature and dynamics of South Africa's service-delivery crisis. In the rest of this section, I shall do so by more deliberately exploring perspectives from the prevailing South African service-delivery debate conducted by critical social-science scholars and commentators. In undertaking this assignment, I do regard it as important to acknowledge my own shortcoming of not being able (at least for the purpose of this article) to contribute to the empiricaldescriptive task (the first of Osmer's beacons) (Osmer 2008:4, 31-78) through an empirical exploration of my own. At the same time, however, and as permitted within Osmer's framework of inter- and cross-disciplinary exploration and dialogue (see Osmer 2008:4, 101-128, 162-172), I do believe that South African practical-theological scholarship has much to learn from the highly critical, normative and empirically informed arguments and perspectives that are advanced in the existing debate about service delivery to effectively address the first two of the questions in Osmer's scheme, namely 'What is going on?' and 'Why is it going on?' (i.e. the two questions that are at the centre of the first two of Osmer's four tasks of practical-theological interpretation: the empirical-descriptive and interpretive tasks) (Osmer 2008:4).

Against this background and in view of a larger process of practical-theological interpretation, I want to take a small step towards developing a more profound understanding of the current service-delivery problem by drawing selectively on perspectives, arguments and broad converging lines of thought that, in the context of the service-delivery debate, have been advanced in books and articles and, especially, 
through the electronic media and independent thinktanks and discussion forums on the internet. Yet I do not pretend to do full justice to the complexity of the issue and the considerable range of material and perspectives that already form part of the debate. Instead, and also because of limited space, I merely intend to highlight what I perceive so far, on the basis of closer scrutiny of existing material, to be important elements in an ongoing and intensifying discussion of the problem.

Thus, to pick up the discussion where this article started, it clearly appears that, in the current debate about service delivery in South Africa, the use of the notion of 'social crisis' as hermeneutical lens can be well justified by the way in which the problem in its broad manifestation is equated to the precarious living conditions of the masses of poor Black communities under apartheid as well as to the dynamics of the protests in which those communities reacted against their circumstances (Alexander 2010:37; Holden 2012:333). Yet, it is within such a comparative framework that I would consider Peter Alexander's already mentioned thesis on the current social-delivery crisis as 'a rebellion of the poor' (Alexander 2010), if not 'a massive rebellion of the poor' (Alexander 2012), as particularly instructive in beginning to develop a more profound orientation towards and understanding of the crisis. By looking more closely at the argumentation that informs the thesis offered by Alexander (a prominent sociologist and holder of the South African research chair in social change), the uninformed reader may learn about significant research and statistics that reveal a disturbing and ongoing increase in protest action mobilised from within townships and informal settlements across South African society (see Alexander 2010, 2012). This led Alexander to conclude his most recent analysis by stating that the 'rebellion is massive' and that he had 'not yet found any other country where there is a similar level of ongoing urban unrest' (Alexander 2012).

Whilst it may be conceded that Alexander's perspective on the ongoing increase in protest action is not so uniquely new, in the sense that there are many others in the servicedelivery debate offering a similar perspective (see e.g. Davids 2012a, 2012b; Eyewitness News 2012; Holden 2012:333-336; Von Holdt 2011:5), I do, however, believe that his thesis importantly captures the sociological reality of a new politicisation of the related issues of service delivery and poverty in contemporary South Africa. In terms of his own analysis, he offers a perspective in which he anticipates that there may well be no return from this point of new politicisation as he doubts the ability of government to turn things around to provide the necessary resources, services and capacity to address inequality and effect positive social change (Alexander 2012:38). His conclusion is that the waves of protest 'reflect disappointment with the fruits of democracy' (Alexander 2010:37), which, in terms of one potential scenario, could lead 'into the development of a revolutionary movement' through a generalisation of struggles involving ever more 'interconnections between townships and between township struggles and other arenas of conflict' (Alexander 2010:38; cf. Holden 2012:332, 345-346).

Moving beyond Alexander's thesis, it is striking how frequently the anger of communities is presented by participants in the service-delivery debate as the reason for people's protest action. In South Africa, these authors proclaim, communities of the poor are protesting because they are angry (see e.g. Centre for Sociological Research (CSR) 2009; Davids 2012a; Hattingh 2009; Managa 2012; Patel 2012; Sacks 2012a; Saunderson-Meyer 2012). However, instead of there being one single cause, a chain of interrelated causes may be identified to explain this collective anger, namely why so many of the country's poorest communities are angry and consequently protesting to the extent that their protests have turned violent.

One explanation appears in a recent article by Jared Sacks, a social-justice activist working in the field of nongovernmental organisations (NGO), on the protest politics involving the residents from the informal settlement known as Sweet Home in the Philippi area of Cape Town. On the basis of interviews with people on the ground, Sacks presents the following list of reasons why residents from this community were angry and felt compelled to protest in such a disruptive way by blockading roads, burning tyres and destroying traffic lights:

- Their garbage was not taken away every week as in other parts of the city, leaving the settlement extremely dirty, unattractive and unhygienic.

- Most of their toilets were broken, leaking and otherwise unsanitary.

- Only some residents had been connected to an electricity supply.

- Open-air sewage canals built by the city were unsanitary and unsafe for children. Along with this, a nearby business had also blocked the canal with the result that raw sewage flooded into homes when it rained.

- The subsequent effect has been severe health issues for children, the elderly and other residents.

- Their anger was also directed at the local ward councillor for not working with residents to meet their needs and for ignoring residents when they attempted to engage with him on issues (Sacks 2012a).

Thus, writing on behalf of the people, Sacks indicates in his list why the miserable living conditions and experience of public neglect and sub-standard service provision in a poor local community in South Africa constitute the basic causes of the anger and civic protest. Although for some a contested idea in the service-delivery debate, in this list, it is also suggested that part of the source of this community's anger was its members' sense of 'relative deprivation' (cf. Alexander 2010:32; Hall 2012; Holden 2012:337-339). In their community, they were not provided with the same services as other parts of the city were whilst the services and infrastructure provided were of a dismal standard. Importantly, it also did not stop here, as the last of Sacks's listed reasons suggests along with the larger whole of his 
article. In Sweet Home, residents were also protesting because of their futile attempts to engage with the local governmental or municipal leadership regarding their dismal situation and because that leadership subsequently persistently ignored and disrespected their plight. This consequently led to the perception that this kind of protest was their only way of getting the attention of government (Sacks 2012a).

Sacks's account of the community of Sweet Home provides a good and concrete case, within the context of the wider service-delivery debate, of the causes that have at the most basic level been fuelling the anger and subsequent protest actions of so many poor communities in the country's townships and informal settlements (cf. CSR 2009; Centre for the Study of Violence and Reconciliation and Society, Work and Development Institute [CSVR \& SWOP] 2011; Patel 2012; Sacks 2012b). At the same time and no less important, however, it is also in this account that we start to develop an impression of how strongly the emphasis in the servicedelivery debate has come to fall on the deficiencies and failures of local government to explain the service-delivery crisis and people's reaction to the crisis.

In terms of the broader debate, one of the deeper explanations of the neglect and disregard on the part of local governmental leadership and representative bodies is that, as part of a new elite, they simply do not care and in fact regard the need to provide services to the poor 'as a burden' (Hattingh 2009; cf. Von Holdt 2011:20-22). In even more crude terms, according to this perspective, the kind of services provided to townships is to be explained by 'the reality that the elite view township residents as being little better than animals' (Hattingh 2009). In contrast to this understanding, another group of explanations has rather placed the emphasis on the lack of capacity in local government to deliver. Thus for one commentator, it is simply a case that government 'can't fix what's wrong' because '[i]t is a competency issue ... [and] not an awareness one' (Hlongwane 2012; cf. Satgar 2012) whilst for another it is local government that, in more proactive terms, is faced with major challenges in order to become effective. These include the lack of institutional capacity at municipal level, the problem of financial management on a large scale, high levels of corruption and the lack of public participation (Managa 2012:3-5; cf. Patel 2012).

Whilst not unrelated to the above perspectives, other commentators in the debate have gone even further by interpreting the deficiencies and failures of local government as essentially a crisis of democratic governance itself in postapartheid South Africa. In this interpretation, therefore, the problems of local government are effectively seen as a crisis of governance and of the state in its broadest manifestation: the governmental and state apparatus are simply not geared towards the principles of participatory governance and are authoritarian and technocratic in their very nature, outlook and approach to development. According to this perspective, these features are especially evident in those cases where local government and the state at large in fact do provide services to poor communities as in these cases the common tendency is that decisions are taken on behalf of poor communities, often with dire consequences for them not only in terms of the quality rendered but also in terms of the wider social suffering inferred upon them (such as, for example, in housing where forced removals from welllocated shacks to peripheral housing developments are a common phenomenon or where shack renters are left homeless when houses are provided only to shack owners) (Pithouse 2009, 2011; see also Friedman 2009; McKinley 2011; Pithouse 2010; Satgar 2012; Saunderson-Meyer 2012).

An important conclusion for proponents of the democratic perspective is therefore that the automatic use of the term 'service-delivery protest' often obscures more than it illuminates (Pithouse 2009; see also Friedman 2009; Pithouse 2011). Instead the contention here is that the protests should be understood not so much only as people's demands for more or more efficient service delivery but rather as expressing their reactions against the way the state goes about actually rendering services and consequently also their demands for a more inclusive model of development whereby they are heard and taken seriously. Below, I quote one of the prominent proponents of this position (Steven Friedman), more specifically with regard to the distinction he has been making in his own discussion between the notions of 'service delivery' and 'public service' and his subsequent argument that the protests have in fact been a demand for the latter:

There is a great difference between 'service delivery' and 'public service'. The first entails officials - and commentators - deciding what people need and then dumping it on them. As Mangcu and Pithouse point out, and Diepsloot shows, this refusal to allow people to make their own choices is particular prevalent in housing, but it happens in other areas too: the removal of small traders from areas where some 'service deliverers' think they ought not to be is another grievance that prompts protest. Many local protests are reactions against this high-handedness and so are, in reality, protests against 'service delivery'...

Public service, by contrast, starts from the recognition that, in a democracy, the government's job is not to 'deliver' to citizens. It is, rather, to listen to them, to do what the majority asks, if that is possible, and, where it is not, to work with citizens to ensure that what is done is as close to what they want as it can be. It stems from the core democratic idea that government works for citizens and that it cannot do this unless it listens to them. ... The protestors are demanding public service, not delivery. (Friedman 2009)

Enough has perhaps been said up to this point to begin to form some impression of the complexity of the post-apartheid service-delivery problem and how it may well be indicative of a deepening social crisis in contemporary South African society. So in concluding this section, it seems to me quite important to finally also touch upon two further themes that surface fairly strongly in the current service-delivery debate: the issues of 'violence' and 'economic neoliberalism'.

Regarding the issue of violence, firstly, it seems rather obvious that participants in the debate would give deeper 
consideration to the increasingly violent nature of protest action and the way in which police forces have on their part also become increasingly visible in countering protest actions through their own forms of violent action (see e.g. Von Holdt 2011:26-30). So, for instance, in what appears to be a line of thinking strikingly similar to the position of M.J. Manala highlighted in the previous section, participants in the debate have appreciated not only the intrinsic value of forms of protest action, such as the construction of road blockades, but also the destruction of property to enforce communication with political authorities and express the democratic aspirations of protestors (Pithouse 2010; Sacks 2012b; see also Majavu 2011:4; Nicholson 2012). In the context of a constitutional democracy such as South Africa's, the argument further advanced is that the state and actors of mainstream civil society have no right to label such and other kinds of (violent and non-violent) protest illegitimate and antisocial per se. Instead such forms of protests could be perfectly justified in the context of this democratic reality, especially in a situation where people's democratic freedoms and opportunities for development are suppressed through growing party and state authoritarianism in the form of police and party violence as well as party-political interests. In such a situation, the state and civil society therefore have no right to declare popular forms of protest illegitimate until and unless a point has been reached where the actions of both 'are beginning to turn the tide against economic and political exclusion' (Pithouse 2010; see also Hattingh 2009; Sacks 2012b).

However, it should be mentioned at this point that this line of thinking has been problematised and complicated in an important way by what could certainly be regarded as one of the most profound contributions so far to the service-delivery debate: a recent project involving eight case studies of community protest and xenophobic violence in South Africa undertaken collaboratively by The Centre for the Study of Violence and Reconciliation (CSVR) and the Society, Work and Development Institute (SWOP) at the University of the Witwatersrand (CSVR \& SWOP 2011). Thus, whilst similar to the first line of thinking upholding a theory on how the collective participation of servicedelivery protestors in violent confrontation may have an empowering (or emancipatory) effect on them, the CSVR and SWOP study also goes to some lengths to point to the corrosive effects of violence on South African society as a whole (Von Holdt 2011:28-29, 32). In this regard, the study points out quite disturbingly how South African society in fact finds itself entrenched in 'cycles of collective violence' (Von Holdt 2011:29) in which both groups of protestors or subaltern citizens (which significantly includes a substantial part of the country's youth) and the police or elite or state view the use of violence as a natural and justified response in an ongoing process of class formation and consequent struggle over inclusion and exclusion in the new democratic South Africa (Von Holdt 2011:20-24, 26-32). Whereas it is acknowledged that a tradition of collective resilience and resistance to violence still prevails in South African society
- not least in some of the case-study areas where histories of peaceful protest appeared to have preceded the violent clashes with the police (Von Holdt 2011:32) - the study further suggests in an innovative way that the prevalence of collective violence in present-day South Africa should be understood as a symptom of a society that not only still suffers deeply from the 'collective and unresolved trauma of apartheid' but now also from 'the collective trauma of the paradoxical new democracy' (as well reflected, for instance, in the service-delivery crisis) (Mogapi 2011:122-124).

Finally, then, regarding the second of the two issues mentioned above, it is evident that a number of critical participants in the service-delivery debate have identified the adoption of a neoliberal model of political-economic practice in post-apartheid South Africa as the major underlying cause of the current service-delivery crisis (see Alexander 2010:37; Bond 2008; Hattingh 2009; Majavu 2011; McKinley 2011; Pape \& McDonald 2002; Satgar 2012). Thus, for instance, in two penetrating analyses that bring us back to a focus on local government in South Africa, the authors similarly claim that the origins of the current state of crisis in local government as a service-delivery agent may be found in the full deployment of neoliberal economic policies from the mid-1990s onwards through what has become known as the Growth, Employment and Redistribution (GEAR) macroeconomic policy (McKinley 2011; Pape \& McDonald 2002:2$7)$. In effect, through the fiscal constraints that were now imposed by central government on local governments (as a result of GEAR), the latter were not only forced to drastically cut back on service-delivery targets but were in fact also abandoned 'to [their] own devices' (McKinley 2011) to gain revenue and deliver services. This subsequently led to the situation where the logic of the market would now become ever more prevalent (Pape \& McDonald 2002:5) and where local governments would increasingly be run like private businesses (McKinley 2011). The result would be disastrous especially for the poor as municipalities would now increasingly prioritise 'cost recovery' mechanisms to gain revenue, resulting in the cutting off of basic services such as water and electricity in those communities least able to afford payment; increasing the costs of services to maximise their own income and profits; rendering the standard of services in accordance with what people can afford; privatising or corporatising the management and delivery of basic services, leading to unaffordable charges and prioritising the delivery of services to those able to pay (McKinley 2011; Pape \& McDonald 2002:5-6).

For critics of the neoliberal turn, furthermore, it has been important also to draw a direct correlation between the abovementioned developments and those corrosive elements in post-apartheid local government that have become the focus of so much critique in the service-delivery debate. Thus in this perspective, the new drive towards privatisation, outsourcing and profiteering at all costs became the natural breeding-ground for cultivating the elements of corruption, patronage and self-enrichment that have become so endemic 
and that have in fact been at the heart of democratic erosion at the local level. As a direct consequence, in terms of this connection, the focus on service delivery has thus become part of a broader systemic perspective juxtaposing an exploitative elite in relation to poor citizens in a vast and increasingly unequal society (see Alexander 2010:37; Hattingh 2009; McKinley 2011; Satgar 2012; cf. Bond 2008; Majavu 2011; Pape \& McDonald 2002:2-7). In the provocative words of one commentator:

The elite have not been content with just waging a war on workers and forcing people into unemployment, but have literally attacked all township residents by snatching up the few commons that exist. As part of this, vast sections of the public service sector have been privatised and handed over to the local and global elite to profiteer from. This has seen the elite selling basic services, such as water and healthcare, in order to make a fortune. Even when public services are not fully privatised, they have been commercialised by the state. This means that the state runs the remaining 'publicly' owned services to maximise profits. The poor and unemployed who can't afford what corporations or the state now charge for these services are viewed as bad apples and simply cut off. In fact, over 10 million people have had their water or electricity cut in South Africa since 1996. (Hattingh 2009)

\section{Modes of diaconal practice in contexts of endemic poverty}

It is with reference to the further beacons of practicaltheological interpretation presented in Osmer's scheme - the normative and pragmatic tasks addressing the questions 'What ought to be going on?' and 'How might the Christian church or faith community respond?' (Osmer 2008:4) - that I will now devote the rest of this article to the second major undertaking indicated in the introduction. In light of the attempt towards contextual understanding of South Africa's service-delivery crisis in the preceding section, I will more pertinently consider what the church may offer in terms of its own service to society - or put differently in more peculiar theological language, in terms of its own diaconal response - to make a transformational difference to the crisis and by implication the living conditions of numerous communities of the poor that are suffering from the crisis.

However, I should state that I do not intend to present a conclusive or finally developed perspective in the following discussion. Rather, in the absence of any direct engagement with the contextual issue of South Africa's service-delivery crisis in the field of practical-theological scholarship (i.e. besides M.J. Manala's single effort), my approach here will be to build on existing conceptualisations of what I would like to refer to as different 'modes of diaconal practice' and to critically consider their merits in the light of my own attempt towards developing a contextual understanding of the service-delivery problem. In other words, by drawing upon two worthwhile and more developed conceptualisations on offer in South African and international practical-theological scholarship, respectively conceptualisations whose relevance to the topical issue of South Africa's service-delivery crisis is suggested by the way in which they relate their diaconal concerns to contexts of endemic poverty, my ultimate intention is to critically reflect on the extent to which these conceptualisations may be considered as providing a sense of direction in conceptualising a transformational diaconal response to the service-delivery crisis.

\section{Diaconal practice as congregational projects of community development and charity inspired by prophetic preaching}

In South African practical-theological scholarship in the post-apartheid era, the work of Hendrik Pieterse deserves special appreciation for the way in which he has developed, through on-going research over a prolonged period of time, a theoretical perspective on the role that the Christian church could play through its preaching to promote diaconal practices of social change in South Africa's many poor communities (Pieterse 2001, 2002, 2004, 2011a, 2011b, 2012, 2013a, 2013b). Having himself drawn attention to his research interest in developing 'a homiletic theory for praxis which will help preachers to communicate the gospel's message meaningfully in the South African situation of poverty' (Pieterse 2004:93; see also pp. 3, 15), Pieterse views as an important underlying assumption the claim that the church cannot view preaching alone as sufficient for liberating people from poverty. At the same time, however, he insisted that this element of the church's worship or ritual activity represents a potentially powerful medium to inspire and activate local congregations to become practically involved in the struggle against poverty in poor communities (Pieterse 2002:560, 2004:118; cf. 2011a, 2012, 2013a, 2013b). Accordingly, in Pieterse's work, a homiletic interest has been inextricably connected to the field of diaconia to develop a practical-theological theory of action for a post-apartheid South African society still suffering severely under conditions of endemic poverty (see Pieterse 2004:93-121, 2011a:2).

Against this background, it follows that Pieterse's combined homiletic and diaconal interest can only be fully appreciated by taking account of the profoundly contextual approach in his work. Having been deeply influenced in his own academic development by the hermeneutical insights of philosophers such as Hans-Georg Gadamer and Paul Ricoeur, but also by South African liberation theologians, Pieterse referred to his own approach as 'Reformed liberational' (Pieterse 2002:555-556). From a homiletic point of view, this approach entails that the process of understanding a biblical text for the purpose of preaching on a Sunday should fundamentally start with the situation of the congregation to whom the sermon will be delivered. Furthermore, it also entails that, when the situation of the congregation - the circumstances, experiences, needs and problems related to the context of its members - is confronted with the biblical text in the next step of interpretation, this is done from the standpoint of 'the preferential option for the poor', which requires that the Bible is approached and read from the perspective of the poor (i.e. poor Black and White people in the South African context) (Pieterse 2002:557-559; see also 2004:17-21, 79-88, 115-116). 
For Pieterse, then, a position of a preferential option for the poor is well justified by the Bible's own revelation about God's special concern and compassion for the poor (Pieterse 2004:82-85). Yet it is a position that also finds important support in the contextual reality that (with the exception of a very small minority of its people) South Africa is a poor country (Pieterse 2002:557; see also 2001:75-78, 2004:28-70). This recognition subsequently leads him to identify two further central markers in his theological-hermeneutical framework aimed at preaching in a context of poverty. Firstly, in order to do justice to the position of a preferential option for the poor and before engaging in the act of preaching, preachers need to experience the situation of the poor existentially through direct exposure and dialogue which will entail empirical social analyses but even more importantly acts of 'pastoral closeness' to the people (read 'the poor') (Pieterse 2004:85-88). Essentially this entails that preachers have:

... to listen to people's stories and their views of life, God, the church, the government and other people. By being with them in their distress, by taking their side, by supporting them pastorally and showing them God's love, one starts gaining their trust. The preacher has to see life, religion, God, the government and other people through the eyes of the people. That is what it means to acquire existential knowledge of their context and of them as human beings. (Pieterse 2004:86-87)

Secondly, in order to do further justice to the position of a preferential option for the poor but now as an integral dimension of the message that is preached on the basis of exposure to both the context of the poor and the biblical text, preachers need to engage in a mode of preaching known in the tradition of South African liberation theology as 'prophetic preaching'. This means that preachers taking this option will in their sermons inspire the faithful - and in particular the faithful poor - in a new way with a message of hope on the basis of God's liberating word in the biblical text. At the same time, they will also confront head on the situation of poverty and abuses of power in this situation (Pieterse 2002:557, 2004:88-90). Pieterse (2004) describes the essence of this mode of preaching as follows:

We speak of critical, creative hermeneutic association with the present-day context and the context of the text in such a way that the translation of the message in the prophetic sermon holds out new, liberating promises from God to his children. It is critical because our hermeneutic work is ideologically critical. All ideologies that water down the power of God's word in the text for the poor have to be exposed. To the genuinely prophetic preacher it does not matter whether these ideologies are Western, capitalist, socialist, racist, Third World or those of a particular national group. ... All ideologies that weaken and jeopardise the position of the poor have to be identified in prophetic preaching. Abuse of power, no matter by whom, must be pointed out. Such a prophetically critical hermeneutic allows us to interpret the message of the text creatively so that our preaching to the poor may be liberating. (p. 90)

It was important up to this point to have highlighted in some detail the essential aspects of Pieterse's homiletic perspective since it is from this point on in his further endeavour to develop a 'homiletic theory for praxis' that he proceeds by drawing a direct causal relationship between the act of prophetic preaching inspired by a preferential option for the poor and the newly found activation of what he identifies as a 'diaconal, diaconally oriented church' (Pieterse 2001:95, 2004:111). Thus, in what could in terms of his earlier work be considered as a perspective based on particular theological and theoretical assumptions, for Pieterse, this causal relationship could be explained as the outcome of the actual act of prophetic preaching to which the congregation respond faithfully and practically on the basis of their living encounter with God's word through the work of the Holy Spirit (Pieterse 2002:558, 2004:91-92). Yet, at the same time, it is beyond this point of theological explanation that Pieterse almost naturally assumes that the mode of prophetic preaching that he anticipates will activate a kind of diaconal church and diaconal practice that one finds articulated in particular theological theories of diaconia and community development (Pieterse 2001:94-102, 2002:111-121, 2004:111121).

By projecting the idea of a diaconal church as the assumed outcome of reinvigorated prophetic preaching in a postapartheid South African context of endemic poverty, Pieterse proceeds by drawing on the conceptual distinction between the 'church of the poor' and the 'church for the poor' in diaconal theory, which he in turn also relates to the concept of a 'missionary diaconal church' (Pieterse 2001:95-97, 2002:558-559, 2004:111-113). Applied to the South African context of poverty, for Pieterse, it remains realistic and relevant to distinguish between the church of the poor and the church for the poor in defining the existence and role of the diaconal church. Yet in adhering to the theological principle of 'the missio Dei' on which the concept of the 'missionary diaconal church' is founded, both these representations of the diaconal church in South Africa are called upon to join in God's movement 'in the world to reach people in distress' (Pieterse 2001:96-97, 2004:113; see also 2002:558-559). Becoming in this sense 'a servant of God' emulating 'his incomprehensible love for people in distress (John 3:16)', the fundamental implication is that there will be no place for 'any authoritarian action by a (better-off) congregation for the poor for the benefit of those in a church of the poor' (Pieterse 2001:96, 2004:112). Instead, any help that the church for the poor wants to render to those in need will now be conducted within a new 'partnership relation' with the church of the poor in which the latter in fact sets the tone. In this relationship, the congregation of the poor will not only lead congregations for the poor in listening anew to the poor, but they will also 'determine the needs, think of projects and then receive support as they proceed to help themselves' (Pieterse 2001:99, 2004:115-116; see also 2002:559). Hence the ultimate aim of this kind of diaconate becomes the 'liberation' of the poor, which they experience through their faith in God but also from the materially better life that they will now enjoy (Pieterse 2001:98, 2004:114).

Indeed, Pieterse's perspective on the diaconal church in the South African context (as outcome of his envisaged prophetic preaching) has obtained a significant additional conceptual 
element through the way in which he has invented the notion of 'diaconal community development' to further, and in even more concrete terms, describe the mode of diaconal practice that he envisages for this kind of church (Pieterse 2001:99-100, 2002:559-560, 2004:116-118). Whilst observing that " $i] \mathrm{n}$ liberation theology the word "development" has a nasty ring to it' (Pieterse 2001:99, 2002:559, 2004:116), he also comments that this is different in the post-apartheid South African theological context. In this sense, joining others in the post-apartheid theological agenda who have embraced the notion of development as a positive concept (cf. Swart 2008), for Pieterse, the concept of community development clearly supports his understanding of the mode of diaconal practice that he associates with the diaconal church and in fact gives it a practical edge. Community development, he (amongst others) observes, involves a process in which people come together to exchange ideas and collectively seek answers to their problems. It is as such geared towards triggering 'a transformation process', which in the partnership between congregations of the poor and congregations for the poor gives special opportunities to the poor to be heard and listened to as equals (Pieterse 2001:99-100, 2002:560, 2004:117-118).

However, in what brings us to a decisive point in the development of his thinking, for Pieterse, it is of great importance that diaconal practice as community development should, within the above-mentioned parameters of collectivity, 'be geared to economic development' (Pieterse 2001:100, 2002:560, 2004:117) in the sense that poor people are assisted to create employment for themselves in the informal and formal sectors. As such, whereas Pieterse observes that it would be the role of sermons to provide information and motivation in this regard, it is at this point that he introduces us to a perspective or idea even more central to his thinking. The economic empowerment of the poor achieved through the new partnerships between congregations of the poor and congregations for the poor should find its most concrete expression in the launch of different types of 'projects' for socio-economic development in which church members will naturally participate. Significantly, this should not be seen as a totally new terrain for the post-apartheid church, as several examples could be listed of existing project initiatives by churches from which diaconally oriented congregations could learn (Pieterse 2001:100-102, 2002:561, 2004:117-120).

I find it important in the overall context of this article to conclude with the observation of how, in Pieterse's work, his rather radical ideas about prophetic preaching and the mode of diaconal practice that he envisages to emanate from such preaching are ultimately absorbed by his perspective on community-development projects as the most concrete expression of such a practice. Whereas I have so far drawn on his earlier research to come to this conclusion, such an emphasis on projects does not appear to be a lesser feature in the work derived from the more recent and current phase of his ongoing research on the role of preaching in the South African context of poverty (Pieterse 2011a, 2011b, 2012, 2013a, 2013b). Thus, whilst the main distinction from his earlier research could now be considered the way in which Pieterse has been developing his thesis on a direct causal relationship between the act of prophetic preaching and the activation of a diaconal church from his actual undertaking of empirical research, his perspective and his emphasis on projects have basically remained the same.

More specifically, in an ongoing research project in which Pieterse is conducting a grounded-theory analysis of sermons by preachers from the Dutch Reformed Church and the Uniting Reformed Church with Matthew 25:31-46 as sermon text (Pieterse 2011a:1, 2011b:96, 2012:1, 2013a:176, 2013b:2-3), the results so far have enabled him to develop, more than he has been able to do in his earlier work, a substantial classification of projects in which congregations from these two denominations are presently involved. In what may be described as a deliberate attempt to develop, on the basis of an open-coding analysis of sermons on the above-mentioned text, a more diversified and extensive classification of existing projects (see Pieterse 2011a:2, 2012:2) through which selected congregations of the two churches are displaying their concrete care for the poor, Pieterse's work has clearly taken on a new dimension through the way in which he now distinguishes between two categories of diaconal projects amongst the poor on the basis of this analysis. Whilst now making a distinction between 'congregational projects of charity' and 'congregational projects of empowerment' (Pieterse 2011a:7, 2012:5-6, 2013a:187-190, 2013b:6-7) - of which the different subcategories and single examples in the subcategories are listed in Box 1 - he nevertheless remains appreciative of both types of projects as contributing meaningfully to solving the country's poverty problem (see Pieterse 2011a:3-4, 2011b:96) and as presenting signs of a renewed church in the 21st century (Pieterse 2011a:1-2) making a social difference.

\section{Diaconal practice beyond the service-delivery paradigm of mainline middle-class piety}

Can the Christian church in South Africa offer something different to, or more than, the congregational projects of charity and empowerment that Hendrik Pieterse has been upholding in his conceptualisation as an authentic diaconal response to the problem of endemic poverty in the country? It is with this question in mind that I regard it as a most worthwhile exercise to deviate from my direct South African focus in this second subsection to focus in particular on one amongst the few available, worthwhile and more developed conceptualisations in the field of Christian diaconia, namely the contribution that Susanne Johnson - a practical theologian and professor of religious education at Perkins School of Theology in Dallas, Texas - has made to the conceptualisation of a Christian diaconal practice that is critically concerned with the problem of poverty.

Although written first and foremost with her own contemporary American context in mind, Johnson's work in two essays (Johnson 2003, 2004) could certainly be appreciated by an international practical-theological scholarship and its 
BOX 1: Pieterse's classification of congregational projects amongst the poor based on sermon analyses.

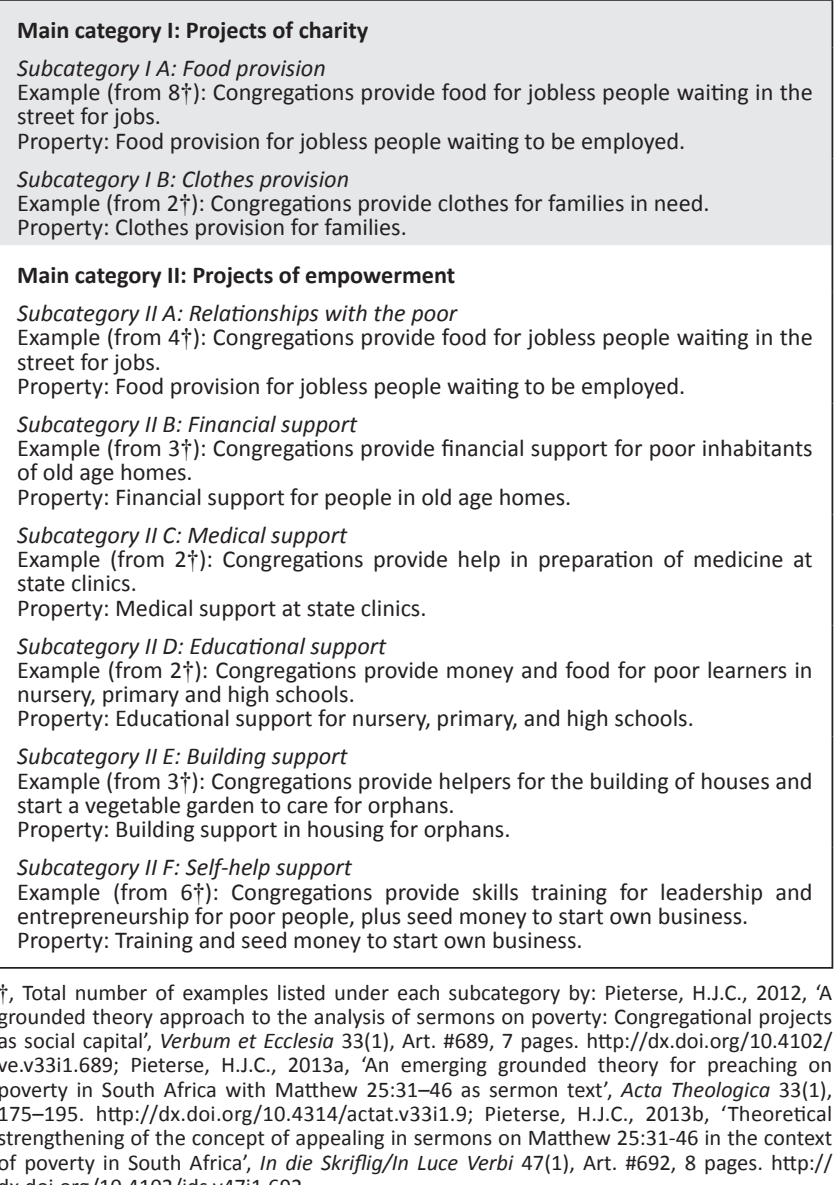
dx.doi.org/10.4102/ids.v47i1.692

sub-discipline of diaconal studies for the way in which she has taken up the universal theological theme of 'remembering the poor' to think critically and anew about contemporary Christian practice in a world largely dominated by economic globalisation and neoliberal market-economic capitalism. Essential to Johnson's argument is that remembering the poor (which finds its direct biblical foundation in Galatians 2:10) could be regarded as 'a concrete, historical practice with a long, varied and rich tradition, grounded in and shaped by faith communities over many centuries' (Johnson 2004:192-193). Yet, for her, of even greater importance is the point that this has today become the historic practice 'most in need of fresh consideration by practical theologians and Christian educators', exactly because too many people are 'disappearing into the underside of history' as a result of 'unfettered free market forces' (Johnson 2004:192).

It follows that Johnson's argument cannot be fully appreciated without taking note of her stringent critique of the moral bankruptcy of the current system and of how mainline Christians (read American mainline Christians in particular) have themselves been culturally compromised by the system. Thus, for her, by taking her own American society as point of orientation but also going beyond it, it is particularly disturbing how the deaths and socio-economic suffering of the masses 'living below' - as reflected, for instance, in the daily death of 30000 children under the age of five around the globe because of starvation and preventable infectious diseases - have come to count for nothing in the present-day world driven by 'corporate-capitalism' (Johnson 2004:193-194). However, particularly disturbing also is how the current system has:

... spawned a capitalism wherein the wealth of the wealthiest 1 per cent of Americans exceeds what 95 per cent of other Americans have to live on, and a globalized economy where the world's 200 richest people own assets greater than the combined income of the world's 2.5 billion poorest people. (Johnson 2004:196)

As such, this inequality reflects a runaway world in which normative human development is seen as being 'best driven forward by ever-escalating competition, consumption, ambition, addiction, achievement, and acquisition' (Johnson 2004:195). It also reflects a dominant neoliberal world view in which:

... private or individual interests in an unfettered, unregulated market is the most efficient means to produce economic growth which eventually will benefit all members and institutions in a given society. (Johnson 2004:197)

This, however, has resulted in a value orientation that is motivated by greed and that sees greed as something good (Johnson 2004:197).

As an important extension of the critical perspective espoused above, for Johnson, it has been important also to point out how 'mainline middle-class Christians' and their congregations (in the USA in particular) are in fact part of the capitalist system, to the extent that they are much more influenced by the values of the free-market model of neoliberal thought than by their own distinctive set of faith practices and beliefs. This has led to their having become so comprised by the 'culture of consumer and corporate capitalism' that they are hardly sensitised to the suffering, hopes and dreams of 'those grassroots communities where families are clinging to life in the undertow of globalized economic forces' (Johnson 2004:195-196). In fact, for them, like others, the worldview promoted by the market model also 'exists as an invisible fact of life', dwelling in them 'without notice' and influencing their Christian practices 'in unknown and unseen ways' (Johnson 2004:198-199).

It is within the above framework of critical understanding that one can observe how it has become important for Johnson to more pertinently ask the question of what the church was doing in the present context to remember the poor (Johnson 2004:199). Thus, in bringing us to a point in her contribution that I consider as particular thought-provoking for a South African practical-theological focus on the theme of service delivery, for Johnson, it has become necessary in response to her question to problematise the notion of 'service delivery' and criticise the fact that mainline congregations (at least in her own American context) 'accepts as pre-given a servicedelivery paradigm as the primary, normative strategy for how the church should go about remembering the poor' (Johnson 2004:199; see also 2003:160). In more concrete terms, for Johnson, this paradigm, which she also calls the 'servanthood model', points to a mode of involvement in 
which the majority of congregations favour 'projects' that address one or more immediate, emergency needs of persons or families for food, clothing or shelter (Johnson 2003:160; 2004:199). Importantly, however, as the 'only' paradigm of ministry that congregations know and stick to, this mode of involvement on a deeper level effectively 'mirrors mainline, middle-class piety' and 'the conventional morality of the white middle-class church in America' (Johnson 2004:200201).

It could be pointed out how Johnson, from this point on, engages in a rather extensive discussion about the importance of power and that, instead of renouncing or denouncing the issue of power, Christians should on biblical grounds exert themselves towards establishing alternative constructions of power (in order to engage the suffering caused by the world's injustice, for example) and a relocation of power and authority (to be distributed amongst and between ordinary persons, including 'the least ones') (see Johnson 2004:202213). For Johnson, this is exactly what never happens in the Christian servanthood model where the position of power remains firmly with the middle class 'serving the needy' (Johnson 2004:208). Accordingly, and this brings us to a key element of her argument, in the Christian servanthood model, everything is said, done, thought and conceived 'from the point of view of the one who serves, never from the point of view of the ones being served' (Johnson 2004:211). Here no attempt is made 'to see the reality of the poor from the perspective of the poor' (Johnson 2004:201) and to act accordingly. In this perspective, service remains defined as that which 'middle- or upper-class Christians unilaterally give or do to and do for another person'. It 'is a one-way street in which the agency of "the other" disappears into thin air' as if 'the ones receiving Christian service have no moral agency, no power, no creativity of their own - only "need"' (Johnson 2004:211).

In terms of the thematic focus of this article, one can begin to appreciate the radical challenge of Johnson's contribution. Clearly the challenge that she poses to a practical-theological focus is to situate the service-delivery theme within a critical moral debate about the kind of world society that global neoliberal capitalism is creating and, as part of this, to develop an equally critical understanding of how mainline churches and their middle-class members in particular are themselves today fundamentally compromised by the ideologies and workings of this capitalist system in terms of their own diaconal practices of 'remembering the poor'. From this vantage point, she further demands from a practical-theological perspective the development of a critical understanding of how the use of the words 'service' and 'service delivery' captures a mode of (conventional) Christian diaconal engagement that emanates from within the ideological and hierarchical world of power represented by the current capitalist system. As such, this mode of engagement should be seen as a powerful compliance with and reinforcement of the realities of this world, a 'one-way' outreach from a position of power and privilege unable and unwilling to develop an understanding of reality from the perspective of the poor, a one-way outreach for that matter also unable and unwilling to be sensitised to the possibility that the current socio-economic and political realities should be newly interrogated from the ethical position of social justice.

Importantly, it is in the light of the critical dimensions argued above that the rest of Johnson's argument may be read as a plea or challenge to practical-theological scholarship to exert itself towards the development of a diaconal ministry in a 'new paradigm' which will address the deficiencies of the service-delivery paradigm and lead to a practice that will 'remember the poor' in a radically different way (Johnson 2003:160, 2004:213). To this extent, it may be observed that, in terms of her new paradigm, Johnson clearly envisions a mode of alternative thinking and practice that will, through its rootedness in particular traditions of faith and theology, inspire a 'new economic orientation' towards radical inclusion and social justice vis-à-vis the institutionalised inequalities and rule of the rich sustained and deepened by the workings of economic globalisation. No less important, however, in this new orientation, Johnson also clearly prioritises a mode of practice that will reverse the service-delivery paradigm's one-way movement from the middle-class (and the rich) and replace it with a vision of a new 'partnership relationship' between Christians - poor and non-poor, working class and middleclass - working together in mutually resisting the institutionalised inequalities of economic globalisation and de facto rule by the rich (Johnson 2004:213-214).

However, as a most important extension of Johnson's vision of a new partnership relationship and as an emphasis equally founded on theological conviction, at the very core of her thinking is the idea that 'primacy' will now be given to the poor and 'to their voice and to their perspective on reality' as a prerequisite for initiating processes of change and renewal. For her, this is indeed the starting point for everything else: where power relations begin to be addressed; where 'in small supportive grassroots groups ... persons pour out their pain, anger, and suffering' and where the stories of such persons 'become the basis for collective critique of ideology' and a starting point for interrogating the wider systemic context (Johnson 2004:214, see also 2003:164-166). Johnson (2004) explains further:

In these grassroots communities, there is no false ideological divide between the personal, the interpersonal, the social, and the structural. Within these settings, persons are provided with a sacred, safe setting wherein they are invited to pour out and to share their personal, private pain, and along with others, translate collective pain into redemptive, public action for the common good. Here, pain, suffering, and anger are given epistemological and moral weight, for they illumine how and where the old order is groaning and manifesting transformational potential under God's renewing of all things in Christ. (p. 214)

For Johnson, then, it is from such a point of personal outpouring that the partnership relationship between the poor and the non-poor or middle-class Christians should 
more actively begin to unfold, and the foremost concern of all Christians will be to engage together in the context of local, distressed neighborhoods' to 'build healthier social environments' in which people from such neighbourhoods could raise their children (Johnson 2002:162, 2004:215). Importantly, however, in what could be appreciated here as more than just good intentions, Johnson goes to some lengths to explain how such a move towards new partnership can draw inspiration from and build on a framework of ideas and practices associated with an already existing movement of community actors and ordinary citizens in the USA and elsewhere in the world working towards the goals of 'community revitalisation'. Accordingly, for Johnson, this movement may inspire in new ways because of the way in which its protagonists - which notably include a strong faith-based presence - have been finding common ground in three distinguishable but interrelated practices or strategies to work for the social and economic revival of distressed neighbourhoods and communities: 'community organising', 'community building' and 'community development' (Johnson 2003:160-166, 2004:215).

In so far as Johnson has therefore laid claim to the interrelated strategies of community organising, community building and community development as explicit 'faith-based' diaconal practices that poor and non-poor or middle-class Christians should pursue in their newly found partnership relationship, this subsection can well be concluded by returning to the question with which I started my discussion of Johnson's conceptualisation. By introducing us to the concept of community revitalisation and relating it in turn to the above-mentioned three strategic concepts, Johnson clearly advocates a mode of interrelated (faith-based) practices that extends beyond individual projects and works towards more wide-scale, overall community transformation. Accordingly, the idea that collective action emanates from faith-inspired visions of 'cultural' and 'economic alternatives' to current forces of economic globalisation based on a commitment to social justice and inclusion are far more pronounced (Johnson 2004:214). Through practices and initiatives that give concrete manifestation to the three interrelated strategies of community organising, community building and community development, the emphasis now falls on the initiation of processes of 'revitalisation', 'redevelopment' and 'reinvestment' in poor communities, kick-started by residents' identification of their available assets but also of the resources they need (Johnson 2004:215). Importantly, also, it is to this end that the mediating, communityorganising role of churches and other faith-based structures are particularly appreciated, not only 'to create a new culture of conversation wherein working class families have more effective voice and visibility in their own neighbourhoods and communities' (Johnson 2003:163) but also 'to connect people and institutions across neighbourhood lines, from all geographic and economic sectors of a city, town, or village (Johnson 2003:163). This may be achieved through broadbased redevelopment and reinvestment through a plethora of programmes, practices and initiatives (see Johnson 2003:162-164), examples of which are listed in Box 2.
BOX 2: Johnson's list of examples of programmes and practices of faith-based community revitalisation.

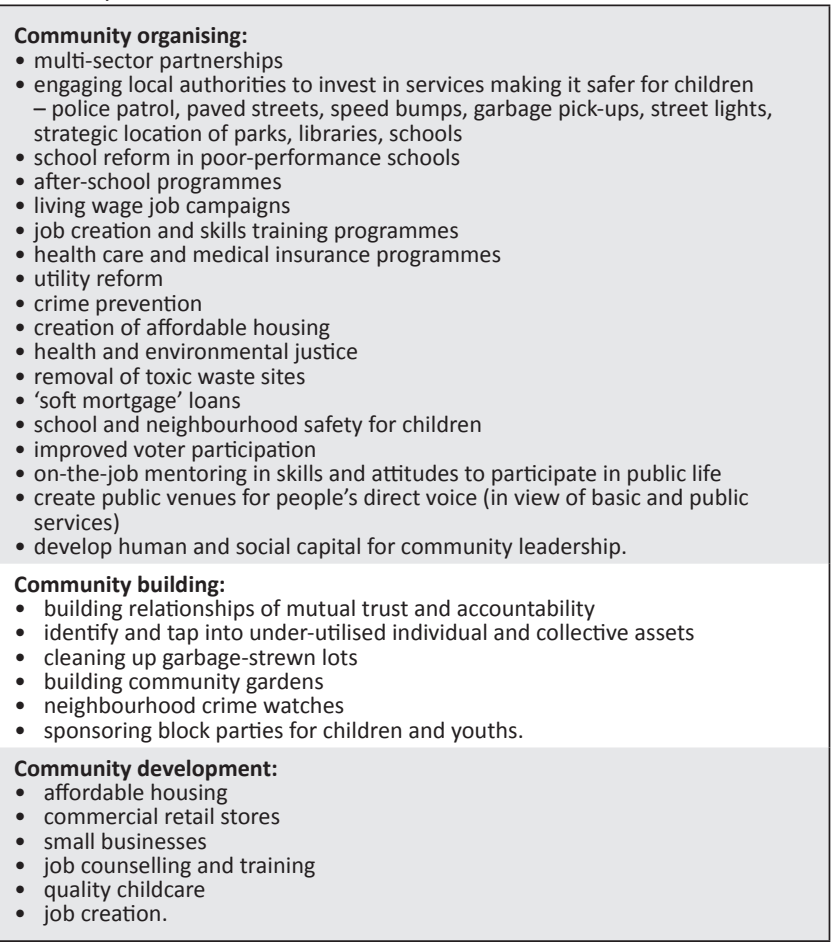

Source: Johnson, S., 2003, 'Women, children, poverty and the church: A faith-based community revitalization approach to addressing poverty', in P.D. Couture \& B.J. MillerMcLemore (eds.), Poverty, suffering and HIV-AIDS: International practical theological perspectives, pp. 155-168, Cardiff Academic Press, Cardiff

\section{Concluding reflections in view of a transformational interest}

In this article, the recognition that the theme of service delivery constitutes an essentially new topical focus for practical-theological scholarship in South Africa led me to an attempt to go the full circle of practical-theological interpretation (as presented in the work of Richard Osmer) in starting to develop such a focus. Having stated my intention to develop this focus from a specific interest in the field of Christian diaconia, a twofold undertaking followed: I, firstly, attempted to develop a deeper contextual understanding of the service-delivery problem in the country on the basis of the prevailing South African service-delivery debate. Secondly, I explored the ideas from conceptualisations of two different modes of diaconal practice in contexts of endemic poverty in the practical-theological literature.

In light of the aforementioned undertaking, I now conclude this article with a more pertinent consideration of the extent to which these two conceptualisations - by Hendrik Pieterse and Susanne Johnson, respectively - may be taken as providing direction in conceptualising a 'transformational' diaconal response to the current service-delivery problem. This is done in light of the recognition that the two selected conceptualisations do not have a direct bearing on the service-delivery problem as understood through the hermeneutical lens of 'social crisis' in this article. As such, whilst they basically compensate for the lack of practicaltheological engagement with the issue to date (i.e. despite the single contribution of M.J. Manala), the important question 
here nevertheless remains to what extent these two more developed conceptualisations may seriously be considered as providing some direction to an anticipated diaconal practice that will make a transformational difference to a problem as complex and deep-seated as South Africa's service-delivery crisis.

In endeavouring to answer the latter question, I find it appropriate to first express appreciation for both conceptualisations on the basis of those elements that they clearly hold in common and that should be foundational to any transformation-oriented diaconal response to South Africa's service-delivery crisis. In so far as this crisis points to a problem that severely affects the country's numerous desperately poor communities, a diaconal response aimed directly and explicitly at the crisis can only follow suit in developing a theological and biblical orientation that likewise takes as preferential option its unconditional identification with the plight of those poor communities. In turn, however, this should also lead to such a response realising both conceptualisations' strikingly similar emphasis on the importance of 'partnership' and the 'act of listening' to the poor that should follow from such partnership. Clearly, as the attempt towards deeper contextual understanding in this article suggests, it would in fact be through the conscious adoption of a truly listening mode within a newly found partnership relationship that a diaconal response representative of both the church of the poor and church for the poor could make a profound contribution towards meeting one of the greatest existential needs of poor people and communities suffering under the crisis: to not be neglected, to be listened to, to be given a space to voice their anger and to experience a new sense of inclusion.

Yet, it should be recognised by a diaconally oriented church in South Africa that it cannot underestimate the great complexity of the task of acting as a listener to the plight of the poor suffering under the crisis. Thus whilst the church may be very honest and sincere in seeking to create new spaces for poor people to voice their anger and aspirations, the contextual perspective presented in this article suggests that a diaconally oriented church should crucially come to terms with the fact that it is faced by communities of the poor deeply traumatised by their situation and trapped in acts of collective violence that many members from those communities perceive as the only meaningful response to negotiate their trauma. Clearly this realisation suggests that a new partnership is needed between the practical-theological fields of diaconia and pastoral care and counselling to take the lead, through participatory action research and in collaboration with their ecclesial partners on the ground, in developing a diaconal response suitable for meeting the complexity of the task of listening and in the process dealing with the deep-seated problems of collective violence and trauma.

Proceeding beyond the elements which the two conceptualisations hold in common, the combination of a homiletic and diaconal interest by Pieterse should in my view be regarded as a unique step towards conceptual innovation for any diaconal response seriously concerned with the issue of poverty. Accordingly, this equally concerns a diaconal response to the specific issue of South Africa's servicedelivery crisis. If supported by the homiletic dimension of their ministry along the lines of Pieterse's conceptualisation, the diaconal responses to the service-delivery crisis of local congregations, both of the poor and for the poor, will without doubt find a powerful ally in their preachers' exposure to the crisis, the 'pastoral closeness' that those preachers will consequently develop in relationship to people who suffer most severely under the crisis and, from this vantage point, the awareness-raising role that they will fulfil through their preaching.

Importantly, however, whereas the above homiletic actions should be appreciated for the essential contribution they will make towards the cultivation of a diaconal consciousness and activation of an appropriate diaconal response, it should not escape our attention that it is through the homiletic perspective in Pieterse's conceptualisation that a connection is effectively made with the two documents with which this article has closely associated itself in defining South Africa's service-delivery problem as a 'social crisis'. By explicitly associating himself with the tradition of South African liberation theology and insisting accordingly that the preaching that should emanate from preachers' concrete exposure to the current context of poverty in South Africa can take on no other mode but a prophetic one, Pieterse's theological stance clearly resonates with the aforementioned documents' own emphasis on 'a prophetic theology' (The Kairos Document 1988:25-36) and 'a prophetic ministry' (Concerned Evangelicals 1986:39) as the only acceptable theological responses to what was then perceived as the socio-political crisis of apartheid South Africa.

Having found sufficient grounds in this article to draw a parallel between a particular theological interpretation of the socio-political context of late apartheid and a new-found interpretation of the post-apartheid context to define the current problem of service delivery in the country as nothing less than a social crisis on a national scale, it could therefore be concluded that a diaconal response that will seek to do justice to the gravity of the problem is largely dependent on the mode of prophetic preaching that Pieterse prioritises in his conceptualisation. Indeed, it will be through such a mode of preaching in a multitude of local contexts - with its emphasis similarly on inspiring the poor who suffer under the crisis with a message of hope as well as on confronting the situation in an ideologically critical manner - that a diaconal response emerging from and inspired by such preaching could continue the theological legacy of the documents under discussion and develop appropriate modes of action in the current situation.

Yet, going beyond such considerable appreciation for Pieterse's conceptualisation, I do find it necessary to point 
out a sharp discrepancy between what was once articulated by the two documents as the modes of radical action that had to follow upon the practising of a prophetic theology in the context of the apartheid crisis (participation in the struggle and civil disobedience, amongst others, were listed) (see The Kairos Document 1988:37-40; cf. Concerned Evangelicals 1986:36-39) and what Pieterse has been advancing as the mode of diaconal practice in his conceptualisation. Importantly, however, this critical observation should not detract from the fact that I also find a great deal of conceptual innovation in the ideas around the notions of a diaconal church, partnership and diaconal community development that Pieterse introduces as part of his perspective on diaconal practice. Whilst these different elements of his conceptualisation could be appreciated as extremely valuable and relevant for the determination of an appropriate diaconal response to the current service-delivery crisis, it is, however, in the ultimate emphasis on congregational projects that the weakness of Pieterse's conceptualisation lies.

I find it rather difficult to correlate the radical and challenging inclination of the homiletic dimension of Pieterse's conceptualisation with his ultimate emphasis on congregational projects as the most concrete, practical outcome of the prophetic mode of preaching that he prioritises. Indeed, here the tension in the international theological development debate some years ago between a project-centred approach and one that prioritised more farreaching ideals of social transformation on the basis of critical ideas appears to be relevant again (see Eliot 1987; Swart 2006:57-89, 2010). Echoing that tension or problematisation, it becomes very difficult to understand how the different kinds of projects that Pieterse lists (see again Box 1) will serve on the level of practice and social action as the extension of the critical hermeneutical and ideological position with regard to the issues of poverty and power that he assumes in his argument about prophetic preaching. Clearly, as a diaconal response, we here by and large encounter a reversion to practices of charity that may have some kind of empowering effect for individuals. And in this sense, it indeed also becomes very difficult to see how this mode of diaconal response will make any difference - besides some scattered amelioration - to the deep-seated structural problems of the service-delivery crisis that were highlighted in the contextual exploration in this article.

It is at this point of problematising Pieterse's ultimate emphasis on congregational projects that I find the mode of diaconal practice conceptualised by Susanne Johnson a great deal more appealing in view of my proclaimed transformational interest. I have already pointed out that there is much that their respective conceptualisations hold in common and that I positively appreciate, but Johnson clearly also goes a step further than Pieterse in her critique of a service-delivery paradigm (in which she significantly also problematises social-outreach activities in the form of congregational projects) as conventional mode of diaconal practice and her subsequent emphasis on the need for the church to develop a diaconal ministry in a new paradigm.
By equating the service-delivery paradigm with middle-class piety and by, in turn, relating this identification to a profound economic statement on the workings of global neoliberal capitalism and the ideological attachment of mainline middleclass Christians to this economic system, it certainly becomes significant to refer once more to the criticism of the projectcentred approach in the historical international theologicaldevelopment debate and to point out how Johnson's own line of thinking shows a striking similarity with that critique. In this regard, that critique - much like Johnson's - not only problematised the one-way outreach of rich and middle-class Christians to the poor from a position of power and privilege. In view of true transformation, it also stressed the need for such Christians and their churches to subject their theologies, worldview and value systems to critical introspection and as a direct consequence strive for far-reaching societal renewal and change in radical new formations of partnership and power sharing with poor Christians and their churches (see Elliot 1987; Swart 2006:81-85, 2010:249-253; cf. Swart 2008:134-135).

Applied more specifically to South Africa's service-delivery crisis, it is along the lines of Johnson's conceptualisation that one can anticipate a diaconal church that would truly start to make a transformational difference in those many communities suffering under the crisis. Moving beyond scattered and isolated instances of projects directed to those communities and consciously striving towards strengthening the agency role of people from poor communities within new relationships of power sharing, Johnson's idea that poor and non-poor or middle-class Christians would find new common ground and vision in the multi-dimensional strategic paradigm of 'community revitalisation' could go a considerable way towards compensating for the lack of public service and infrastructure in South Africa's many poor communities, and in the process, they can begin meaningfully to transform those communities into newly flourishing ones. In what would be the initiation of a significant movement for transformation in South African civil society, the extended idea along the lines of Johnson's conceptualisation that such a movement's mobilisation around strategies, programmes and practices of community revitalisation (see again the examples in Box 2) will originate from a conscious effort to counter the exclusionary effects and social inequalities associated with the system of neoliberal economics certainly also strongly appeals to the problematisation of this system in the current service-delivery debate in the South African context (as was pointed out at the end of the section on this debate in this article). Accordingly, by articulating this stance through an alternative ideological and value orientation and concretely illustrating how its programmes and practices of community revitalisation are presenting viable economic and social-development alternatives to economic neo-liberalism, such a movement emanating from a diaconally oriented church in South Africa may well become a meaningful force of alternative social and economic direction in the country.

Finally, I find it necessary to draw attention to what I perceive to be an important shortcoming in the conceptualisations 
of both Pieterse and Johnson as diaconal responses to the current service-delivery crisis. Despite my appreciation of both conceptualisations - in the case of Pieterse especially the relevance of his homiletic perspective and in the case of Johnson the relevance of the challenge that she poses to mainline Christianity and the Christian church on the level of ideological orientation and transformational practice I do find it particularly difficult to relate any aspect of the two conceptualisations more directly to what the contextual exploration in this article has clearly revealed as the political nature of the current service-delivery crisis and the corresponding ever-growing political activism of those many communities that suffer under this crisis. Indeed, notwithstanding the very serious problem of endemic violence to which some commentators in the service-delivery debate are drawing our attention, I would go along with those other commentators who have found sufficient grounds to justify the protest action of communities suffering under the crisis. Whilst this should by no means be understood as a suggestion from my side that any form or culture of vigilantism is justified, at stake here is nothing less than the question how a truly participatory democracy (i.e. in a context where this is clearly still lacking) can be realised without the agency role and consequent activism and protest action of ordinary citizens. As the contextual exploration in this article clearly reveals, it is this quest for a truly participatory democracy - in which the needs, voice, wellbeing and participation of poor and ordinary citizens will truly be taken seriously - that occupies the centre of South Africa's service-delivery crisis. Accordingly, it is this same quest for a truly participatory democracy and consequential critical engagement with the state and other institutional role-players to build good governance that cannot be bypassed by a diaconal church (i.e. in its local, regional but also broadest ecumenical manifestation) that is serious about its contribution to positive social transformation in presentday South African society suffering severely under a servicedelivery crisis (cf. Kumalo \& Dziva 2008).

I certainly do not want to play down the importance of the various dimensions of a diaconal response that have been highlighted in this final section for a diaconally oriented church that seriously aspires to make a transformational difference to South Africa's service-delivery crisis. At the same time, however, clearly much conceptual work still lies ahead to guide such a church to also do justice, in its diaconal response, to the inescapable political dimension of the service-delivery crisis. Pertaining to nothing less than what was at some point referred to in the international ecumenical debate on diaconia as 'the politicization of diaconal praxis' in contexts of endemic poverty and violation of human rights (Padilha 1994:289), it seems quite appropriate to close here by quoting from one of the documents with which I started the discussion in this article. Having assertively claimed that a 'prophetic theology' was the only acceptable mode of doing theology in the crisis context of apartheid South Africa (see The Kairos Document 1988:25-36), The Kairos Document concluded with a statement about the inescapable 'challenge to action' with which the church was faced in making a faithful response to a prophetic theology. Because 'God sides with the oppressed', it concluded that the church was confronted with nothing less than participating in the political struggle of the people who were combating their situation of poverty and oppression:

Christians, if they are not doing so already, must quite simply participate in the struggle for liberation and for a just society. The campaigns of the people, from consumer boycotts to stayaways, need to be supported and encouraged by the church. Criticism will sometimes be necessary but encouragement and support will also be necessary. In other words the present crisis challenges the whole church to move beyond a mere 'ambulance ministry' to a ministry of involvement and participation. (The Kairos Document 1988:37-38)

\section{Acknowledgements Competing interests}

The author declares that he has no financial or personal relationship(s) that may have inappropriately influenced him in writing this article.

\section{References}

Alexander, P., 2010, 'Rebellion of the poor: South Africa's service delivery protests - A preliminary analysis', Review of African Political Economy 37(123), 25-40. http:// dx.doi.org/10.1080/03056241003637870

Alexander, P., 2012, 'A massive rebellion of the poor', Mail \& Guardian, 13 April, p. 34.

Bond, P., 2008, 'South Africa's "developmental state" distraction', Mediations 24(1) viewed 18 December 2012, from http://www.mediationsjournal.org/articles/ developmental-state-distraction

Concerned Evangelicals, 1986, Evangelical witness in South Africa: Evangelicals critique their own theology and practice, Concerned Evangelicals, Dobsonville.

Centre for Sociological Research (CSR), 2009, Service delivery protests: Findings from quick response research on four 'hot spots' - Piet Retief, Balfour, Thokoza, from quick response research on four hot spots - Plet Retief, Balfour, Thokoza, Diepsloot, Report, 01 September 2009, 2012, from http://www.uj.ac.za/EN/Faculties/humanities/researchcentres/csr/ research/Documents/Quick\%20response\%20research\%20into\%20Service\%20
Delivery\%20Protest\%20Hotspots.pdf

Centre for the Study of Violence and Reconciliation and Society, Work and Development Institute (CSVR \& SWOP), 2011, The smoke that calls: Insurgent citizenship, collective violence and the struggle for a place in the new South Africa: Eight case studies of community protest and xenophobic violence, CSVR \& SWOP, Eight case studies
Braamfontein.

Davids, N., 2012a, 'The year that anger boils over' Sowetan E-edition, 11 October, viewed 15 November 2012, from http://www.sowetanlive.co.za/ news/2012/10/11/the-year-that-anger-boils-over?filter=all comments

Davids, N., 2012b, 'Service-delivery protests getting uglier - report', Times LIVE, 11 October, viewed 15 November 2012, from http://www.timeslive.co.za/ thetimes/2012/10/11/service-delivery-protests-getting-uglier---report

De Gruchy, S. \& Ellis, W., 2008, "Christian leadership in "another country": Contributing to an ethical development agenda in South Africa today', in S. De Gruchy, N. Koopman \& S. Strijbos (eds.), From our side: Emerging perspectives on development and ethics, pp. 9-20, Rozenberg, Amsterdam.

Elliot, C., 1987, Comfortable compassion? Poverty, power and the church, Hodder \& Stoughton, London.

Erasmus, J.C. \& Mans, G.G., 2005, 'Churches as service providers for victims of sexual and/or violent crimes: A case study from the Paarl community', Acta Criminologica 18(1), 140-163.

Friedman, S., 2009, 'People are demanding public service, not service delivery', Business Day Live, 29 July, viewed 22 November 2012, from http://www.bdlive. co.za/articles/2009/07/29/people-are-demanding-public-service-not-servicedelivery

Hall, R., 2012, 'Inequality and poverty: Two sides of the same dilemma', in Carnegie 3, viewed 15 November 2012, from http://www.carnegie3.org.za/inequality-andpoverty-two-sides-of-the-same-dilemma

Hattingh, S., 2009, 'The elite and community protests in South Africa', Mostly Water 05 August, viewed 22 November 2012, from http://mostlywater.org/elite_and community_protests_south_africa

Heitink, G., 1999, Practical theology: History, theory, action domains, Studies in Practical Theology, Eerdmans, Grand Rapids, MI.

Hendriks, H.J., Erasmus, J.C. \& Mans, G.G., 2004, 'Congregations as providers of social service and HIV/Aids care', Dutch Reformed Theological Journal/Nederduitse Gereformeerde Teologiese Tydskrif 45(2), 380-402. 
Hlongwane, S., 2012, 'Analysis: Anatomy of delivery protests and their tragic futility', Daily Maverick, 13 November, viewed 15 November 2012, from http:// dailymaverick.co.za/article/2012-11-13-analysis-anatomy-of-delivery-protestsdailymaverick.co.za/ar
and-their-tragic-futility.

Holden, P., 2012, 'Rumbles and rifts: Service delivery protests', in M. Plaut \& P. Holden (eds.), Who rules South Africa? Pulling the strings in the battle for power, pp. 332-346, Jonathan Ball, Johannesburg.

'Increase in service delivery protests', Eyewitness News, 07 August, 2012, viewed 15 November 2012, from http://ewn.co.za/en/2012/08/07/Rapid-increase-inservice-delivery-protests

Johnson, S., 2003, 'Women, children, poverty and the church: A faith-based community revitalization approach to addressing poverty', in P.D. Couture \& B.J. Miller-McLemore (eds.), Poverty, suffering and HIV-AIDS: International practical theological perspectives, pp. 155-168, Cardiff Academic Press, Cardiff.

Johnson, S., 2004, 'Remembering the poor: Transforming Christian practice', in D.R. Wright \& J.D. Kuentzel (eds.), Redemptive transformation in practical theology: Essays in honor of James E. Loder, pp. 189-215, Eerdmans, Grand Rapids, MI.

Kumalo, S.R. \& Dziva, D., 2008, 'Paying the price for democracy: The contribution of the church in the development of good governance in South Africa', in S. de Gruchy, N. Koopman \& S. Strijbos (eds.), From our side: Emerging perspectives on development and ethics, pp. 171-187, Rozenberg, Amsterdam.

Majavu, M., 2011, 'Making sense of municipal revolt', Development in Focus 1(February), 4-5.

Managa, A., 2012, 'Unfulfilled promises and their consequences: A reflection on loca government performance and the critical issue of poor service delivery in South Africa', Africa Institute of South Africa Policy Brief 76(May), 1-7.

Manala, M.J., 2010, 'A better life for all': A reality or a pipe-dream? A Black Theology intervention in conditions of poor service delivery in the democratic South Africa', Scriptura 105, 519-531.

McKinley, D.T., 2011, 'A state of deep crisis in South Africa's local government', in The South African Civil Society Information Service, 10 March, viewed 18 December 2012, from http://www.sacsis.org.za/site/article/635.1

Mogapi, N., 2011, 'Collective violence \& collective trauma: The traumatic past of apartheid and the paradox of the new democracy', in Centre for the Study of Violence and Reconciliation (CSVR) and Society, Work and Development Institute (SWOP), The smoke that calls: Insurgent citizenship, collective violence and the struggle for a place in the new South Africa: Eight case studies of community protest and xenophobic violence, pp. 119-129, CSVR \& SWOP, Braamfontein.

Nicolson, G., 2012, 'In the wake of Marikana, ANC pushing a self-destruct button', Daily Maverick, 17 September, viewed 15 November 2012, from http://dailymaverick. co.za/article/2012-09-17-in-the-wake-of-marikana-anc-pushing-a-self-destruct-
button

Osmer, R.J., 2008, Practical theology: An introduction, Eerdmans, Grand Rapids, MI.

Padilha, A., 1994, 'Diakonia in Latin America: Our answers should change the questions', The Ecumenical Review 46(3), 287-291. http://dx.doi.org/10.1111/j.1758-6623.1994. tb03425.x

Pape, J. \& McDonald, D.A., 2002, 'Introduction', in D.A. McDonald \& J. Pape (eds.), Cost recovery and the crisis of service delivery in South Africa, pp. 1-13, Human Sciences Research Council Publishers, Cape Town.

Patel, K., 2012, 'In Marikana, local government failures in plain sight', Daily Maverick, 10 September, viewed 14 November 2012, from http://www.dailymaverick.co.za/ article/2012-09-10-in-marikana-local-governments-failures-in-plain-sight

Pieterse, H.J.C., 2001, 'The human face of God for the poor', Practical Theology in South Africa 16(1), 75-104.

Pieterse, H.J.C., 2002, 'Communicative rationality and hermeneutical insights for preaching in a context of poverty', Dutch Reformed Theological Journal Nederduitse Gereformeerde Teologiese Tydskrif 43(3/4), 555-562.
Pieterse, H.J.C., 2004, Preaching in a context of poverty, Unisa Press, Pretoria. PMCid:PMC412864

Pieterse, H.J.C., 2011a, 'A church with character and its social capital for projects amongst the poor', HTS Teologiese Studies/Theological Studies 67(3), Art. \#1046, 8 pages. http://dx.doi.org/10.4102/hts.v67i3.1046

Pieterse, H.J.C., 2011b, 'An open coding analytical model of sermons on poverty with Matthew 25:31-46 as sermon text', Acta Theologica 31(1), 95-112. http://dx.doi. org/10.4314/actat.v31i1.6

Pieterse, H.J.C., 2012, 'A grounded theory approach to the analysis of sermons on poverty: Congregational projects as social capital', Verbum et Ecclesia 33(1), Art \#689, 7 pages. $\mathrm{http}: / / \mathrm{dx}$.doi.org/10.4102/ve.v33i1.689

Pieterse, H.J.C., 2013a, 'An emerging grounded theory for preaching on poverty in South Africa with Matthew 25:31-46 as sermon text', Acta Theologica 33(1), 175195. http://dx.doi.org/10.4314/actat.v33i1.9

Pieterse, H.J.C., 2013b, 'Theoretical strengthening of the concept of appealing in sermons on Matthew 25:31-46 in the context of poverty in South Africa', In die Skriflig/In Luce Verbi 47(1), Art. \#692, 8 pages. http://dx.doi.org/10.4102/ids.v47i1.692

Pithouse, R., 2009, 'Burning message to the state in the fire of the poor's rebellion', Business Day Live, 23 July, viewed 22 November 2012, from http://www.bdlive. co.za/articles/2009/07/23/burning-message-to-the-state-in-the-fire-of-poor-sco.za/article
rebellion

Pithouse, R., 2010, 'South Africa: The enduring rationality of revolt', People of Color Organize, 31 October, viewed 22 November 2012, from http://www. peopleofcolororganize.com/analysis/south-africa-enduring-rationality-revolt.

Pithouse, R., 2011, 'The service delivery myth', Development in Focus 1(February), $6-7$.

Sacks, J., 2012a, 'Protest politics: Sweet Home', in Amandla, 21 September, viewed 22 November 2012, from http://www.amandlapublishers.co.za/blog/1613-protestpoliticssweet-home

Sacks, J., 2012b, 'On the politics of protest in Cape Town', in Amandla, 22 August, viewed 22 November 2012, from http://www.amandlapublishers.co.za/ blog/1544-on-the-politics-of-protest-in-cape-town

Satgar, V., 2012, 'The "second phase of the transition": Another dead end?' Amandla 25 July, viewed 22 November 2012, from http://www.amandlapublishers.co.za/ amandla-magazine/121-amandla-issue-2

Saunderson-Meyer, W., 2012, 'Marikana a marker of profound dissatisfaction countrywide', Thought Leader: Blogs, Opinion, Analysis, Mail \& Guardian countrywide, Thought Leader: Blogs, Opinion, Analysis, Mail \& Guardian Online Network, 08 September, viewed 15 November 2012, from http://www. thoughtleader.co.za/williamsaundersonmey
marker-of-profound-dissatisfaction-countrywide

Swart, I., 2006, The churches and the development debate: Perspectives on a fourth generation approach, SUN Press, Stellenbosch.

Swart, I., 2008, 'Meeting the challenge of poverty and exclusion: The emerging field of development research in South African practical theology', International Journa of Practical Theology 12(1), 104-149. http://dx.doi.org/10.1515/IJPT.2008.6

Swart, I., 2010, 'Church, mission and development: Revisiting the pragmatic debate', in I. Swart, H. Rocher, S. Green \& J.C. Erasmus (eds.), Religion and social development in post-apartheid South Africa: Perspectives for critical engagement, pp. 243-259, SUN Press, Stellenbosch.

The Kairos Document, 2nd rev. edn., 1988, in W.H. Logan (ed.), The Kairos Covenant Standing with South African Christians, pp. 1-43, Meyer-Stone Books, New York.

Von Holdt, K., 2011, 'Insurgent citizenship and collective violence: Analysis of case studies', in Centre for the Study of Violence and Reconciliation (CSVR) \& Society, Work and Development Institute (SWOP), The smoke that calls: Insurgent citizenship, collective violence and the struggle for a place in the new South Africa: Eight case studies of community protest and xenophobic violence, pp. 5-32, CSVR \& SWOP, Braamfontein 